\title{
Commentary: Failing aortic root homograft: Considering the transcatheter aortic valve replacement option?
}

\author{
Paul Philipp Heinisch, MD, and Thierry Carrel, MD, PhD
}

\footnotetext{
From the Department of Cardiovascular Surgery, Inselspital, University Hospital, University of Bern, Bern, Switzerland.

Disclosures: Authors have nothing to disclose with regard to commercial support.

Received for publication Dec 27, 2018; accepted for publication Dec 28, 2018; available ahead of print Jan 31, 2019.

Address for reprints: Thierry Carrel, MD, PhD, Department of Cardiovascular Surgery, Inselspital, University of Bern, Freiburgstrasse 18, CH-3010 Bern, Switzerland (E-mail: thierry.carrel@insel.ch).

J Thorac Cardiovasc Surg 2019;158:388-9

$0022-5223 / \$ 36.00$

Copyright (c) 2019 by The American Association for Thoracic Surgery

https://doi.org/10.1016/j.jtcvs.2018.12.092
}

Homograft aortic valve replacement with reimplantation of the coronary arteries (so-called full-root technique) was introduced approximately 30 years ago, and it carries many advantages relative to prosthetic valves. ${ }^{1}$ Homograft dysfunction as a result of degeneration or exceptionally as a result of infection, however, may lead to reoperation. Redo procedures in patients who have undergone previous surgical aortic valve and root replacement with an aortic homograft continue to provide a technical challenge, mainly because of the severe calcifications of the former aortic wall of the homograft. It has been estimated that in the near future, redo root operations may eventually account about $10 \%$ of all ascending aorta surgical procedures. ${ }^{2} \mathrm{Re}-$ operation on the aortic valve only can be performed in a subset of patients with insertion of a new valve within the homograft; all types of prostheses can be used, including mechanical valves, classic tissue valves, and even the sutureless tissue that may facilitate anchoring within the calcified root or annulus. In cases of extensive calcifications or pseudoaneurysm formation, the only option is to completely replace the calcified homograft root. ${ }^{3}$ This may sometimes turn into a technically demanding procedure that leads to significant perioperative morbidity and mortality, even among patients deemed fit for surgical intervention. ${ }^{4}$ Associated risks could even make a conventional open surgical approach prohibitive. ${ }^{1}$

The potential of transcatheter aortic valve replacement (TAVR) technology is also being increasingly considered in patients who are clearly not included in the current official indication areas. ${ }^{1}$ One such area consists of performing TAVR in younger and low-risk patients with previous biologic aortic valve prostheses as valve-in-valve TAVR. ${ }^{5}$ The experience so far is mainly limited to patients who had previously received a commercially available stented tissue valve. ${ }^{1,5}$ There are limited data available on TAVR implantation within a failed homograft.

In this current edition of the Journal, Sedeek and colleagues ${ }^{6}$ present a single-center retrospective analysis of outflow tract? the analyzed data:

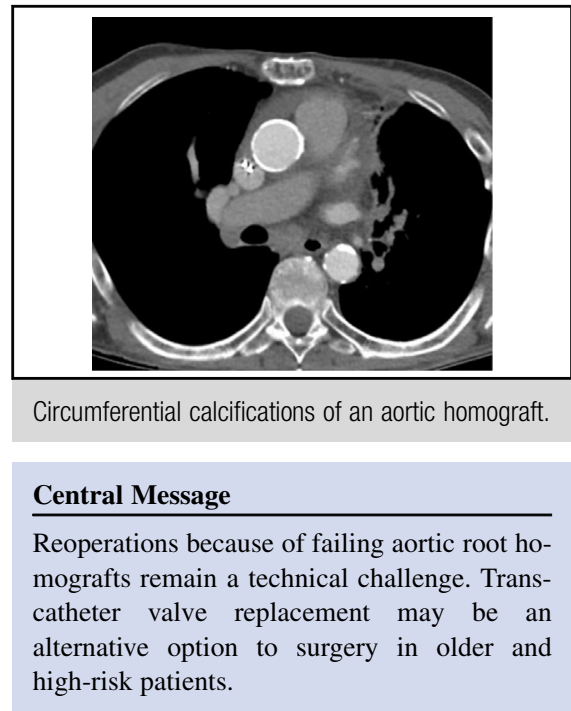

See Article page 378 .

51 patients with degenerated aortic homografts who underwent either TAVR $(n=1)$ or redo surgical aortic valve or root replacement between 2000 and 2018. Sedeek and colleagues ${ }^{6}$ concluded that both TAVR and redo surgical aortic valve or root replacement were associated with notable operative risks and comparable short- to intermediateterm mortalities. TAVR was, however, associated with a lower rate of bleeding and a shorter hospital stay. In addition, an important conic geometric shape of the aortic homograft annulus and left ventricular outflow tract was identified. These incongruous geometric areas of the aortic valve annulus and left ventricular outflow tract disarrange the sizing of the transcatheter aortic valve because of the relatively smaller area size of the annulus $\left(512 \mathrm{~mm}^{2}\right.$; interquartile range, $435-630 \mathrm{~mm}^{2}$ ) in comparison with the left ventricular outflow tract geometric area $\left(677 \mathrm{~mm}^{2}\right.$; interquartile range $490-780 \mathrm{~mm}^{2}$ ). Sedeek and colleagues ${ }^{6}$ raise an interesting question regarding the sizing of TAVR in such cases. Should the transcatheter valve be sized to the geometric area of the aortic annulus or to that of the left ventricular

There are some limitations to drawing conclusions from

- Sedeek and colleagues ${ }^{6}$ relied exclusively on a single type of balloon-expandable transcatheter valve, and 
they have provided no data about the use of selfexpanding valves. Furthermore, the group tended to size to the left ventricular outflow tract geometric area, despite the recommendation to undersize TAVR valves when using balloon-expandable valves. ${ }^{7}$ These results might well have differed had other types of TAVR valves been used.

- The overall conclusion of Sedeek and colleagues ${ }^{6}$ regarding the comparison of TAVR and surgical aortic valve and root replacement may not be firmly based on results from statistical analyses because of the small number of cases and the possible different eras of operations.

- The concomitant cardiac pathologies are being left untreated by Sedeek and colleagues ${ }^{6}$ when they use TAVR in this population. An additional long-term follow-up in the TAVR group will determine whether the failure to treat concomitant cardiac pathologies will affect the long-term outcome. An alternative to the TAVR approach would be the use of rapid-deployment valves in failing homografts, which would provide the ability to treat concomitant cardiac pathologies. ${ }^{8}$

Although the current study of Sedeek and colleagues ${ }^{6}$ cannot provide a conclusive recommendation in favor of the use of TAVR in degenerated aortic homografts, it is clearly an alternative technique to treat patients who face an estimated higher operative risk. It is still unproven, however, whether these potential benefits of the TAVR approach are followed by a better clinical outcome, because data from control groups are lacking. Further extended duration of follow-up is needed to define the long-term outcomes after transcatheter valve replacement for failing homografts. In contrast, repeated surgical aortic valve replacement after homograft root replacement, even in the presence of significant calcification, can be undertaken with an acceptable operative risk, and one should not disregard the consequences of not-treating concomitant cardiac pathologies. ${ }^{3}$

Until today, there has been no evidence to support the routine use of TAVR in degenerated aortic homografts. Doctors and patients should be cautious when considering the TAVR option until there is enough evidence that this provides a satisfactory long-term solution to treat failing homografts, especially in younger patients.

\section{References}

1. Ihlberg L, Sahlman A, Sinisalo J, Rapola J, Laine M. Transaortic valve-in-valve implantation after previous aortic root homograft. Ann Thorac Surg. 2012;94: 1718-21.

2. Pacini D, Murana G, Marco LD, Leone A, Bartolomeo RD. Redo surgery for aortic valve and root: demographics and operative options. In: Fattouch K, Lancellotti P, Vannan MA, Speziale G, eds. Advances in Treatments for Aortic Valve and Root Diseases. Cham, Switzerland: Springer International; 2018:225-35.

3. Sundt TM III, Rasmi N, Wong K, Radley-Smith R, Khaghani A, Yacoub MH. Reoperative aortic valve operation after homograft root replacement: surgical options and results. Ann Thorac Surg. 1995;60(2 Suppl):S95-9; discussion S100.

4. Joudinaud TM, Baron F, Raffoul R, Pagis B, Vergnat M, Parisot C, et al. Redo aortic root surgery for failure of an aortic homograft is a major technical challenge. Eur J Cardiothorac Surg. 2008;33:989-94.

5. Erlebach M, Wottke M, Deutsch MA, Krane M, Piazza N, Lange R, et al. Redo aortic valve surgery versus transcatheter valve-in-valve implantation for failing surgical bioprosthetic valves: consecutive patients in a single-center setting. $J$ Thorac Dis. 2015; 7:1494-500.

6. Sedeek AF, Greason KL, Nkomo VT, Eleid MF, Maltais S, Williamson EE, et al Repeat aortic valve replacement for failing aortic root homograft. $J$ Thorac Cardiovasc Surg. 2019;158:378-85.e2.

7. Barbanti M, Leipsic J, Binder R, Dvir D, Tan J, Freeman M, et al. Underexpansion and ad hoc post-dilation in selected patients undergoing balloon-expandable transcatheter aortic valve replacement. J Am Coll Cardiol. 2014;63:976-81.

8. Danesi TH, Minniti G, Cresce GD, Favaro A, Magagna P, Auriemma S, et al. Redo after failure of aortic homografts with a rapid deployment valve. Ann Thorac Surg. 2016;102:e281-2 